\title{
Undergraduate Nursing Students' Motivation for Learning
}

\author{
Raquel de Abreu Barbosa De Paula1,2, José Lúcio M. Machado ${ }^{3,4}$, Valéria M. P. Machado ${ }^{3,5}$ \\ ${ }^{1}$ Health of the Sao Caetano University, Sao Paulo, Brazil \\ ${ }^{2}$ College Coast South Paulista, Praia Grande, Brazil \\ ${ }^{3}$ Civil Servant Sao Paulo Hospital-IAMSPE, Sao Paulo, Brazil \\ ${ }^{4}$ Department of Surgery, Botucatu Medical School-UNESP, Sao Paulo, Brazil \\ ${ }^{5}$ Medical School, Sao Caetano do Sul University (USCS-SP), Sao Paulo, Brazil \\ Email: pesquisa.raquel@gmail.com, jluciomm@yahoo.com.br, vmmp28@yahoo.com.br
}

How to cite this paper: De Paula, R. A. B., Machado, J. L. M., \& Machado, V. M. P. (2021). Undergraduate Nursing Students' Motivation for Learning. Creative Education, 12, 2180-2195.

https://doi.org/10.4236/ce.2021.129167

Received: August 7, 2021

Accepted: September 23, 2021

Published: September 26, 2021

Copyright $\odot 2021$ by author(s) and Scientific Research Publishing Inc. This work is licensed under the Creative Commons Attribution International License (CC BY 4.0).

http://creativecommons.org/licenses/by/4.0/

(c) (i) Open Access

\begin{abstract}
This paper aims to evaluate nursing students' academic motivation, using as methodology descriptive research with quantitative approach. The result indicates a significant statistic of students already working in the nursing technical area $(p<0.001)$. The results show self-determined motivational profile in regard to motivations and academic perspectives, with higher level of motivation autonomy, featuring students committed to satisfying their personal and professional need for development. It was verified the absence of motivation in small groups of students. The conclusion indicates that learning about the students' academic motivational profile highlights the importance of examining the continuous process of self-determination, following paths for growth and quality of human relatedness, and giving us a glance into effective and significant learning toward excellence in the professional training and efficient and humanized professional practice.
\end{abstract}

\section{Keywords}

Motivation, Learning Nursing, Higher Education, Organizational Innovation

\section{Introduction}

The study of motivation is relevant because it leads us to examine human behavior, expectation, autonomy, competency, satisfaction, and self-determination, especially in seeking a humanized nursing training and practice.

Motivation is a scientific construct with multiple dimensions, which can be approached using quantitative and qualitative methods, gathering countless interpretations and theories developed over the years. 
The theories presented by researchers have a starting point in different movements which influenced the theory of motivation premises.

Historically, the concept of motivation is developed with initial theories of motivation. Considering the contemporary context, the behaviorist movement and the cognitive movement culminated in behaviorist theories (Ryan \& Deci, 2017).

Regarding the initial theories of motivation, it is possible to highlight John B. Watson (Watson, 1912), creator of the "methodological behaviorism", Robert Woodworth (Woodworth, 1918) who developed the "behavior-primacy theory" and William McDougall (McDougall, 1923) who developed the "instinct theory of motivation" (Muacho, 2013).

The "behaviorist movement" had as its main contributors: John B. Watson (Watson, 1913), founder of "behaviorism in the western hemisphere", Edward Thorndike (Thorndike, 1913) developed the "law of effect", John Dewey (Dewey, 1986), philosopher, educator and psychologist, creator of the "general theory of experience and thought", pioneer in functional psychology, Clark Hull (Hull, 1943) developed the "drive reduction theory" (Schwartz, 2019) and Burrhus Frederic Skinner (Skinner, 1958) who developed the theory of "operant conditioning" (Sampaio, 2005). The "instinct theories of motivation" developed studies about instinct behavior based on the reasons which lead an individual to action, however, they were not sufficiently considered for understanding human behavior. In addition, the "movement of cognitive motivation" developed by: Edward Chase Tolman (Tolman, 1932) who considered important to identify different learning types, Julian Rotter (Rotter, 1954) who developed a theory of social learning and locus of control, Albert Bandura (Bandura \& Walters, 1963; Bandura, 1986) who developed the "social cognitive theory", and Victor Vroom (Vroom, 1964) developed the "expectancy theory" (Rotter, 1966; Lobos, 1975; Murray, 1964; Bandura, 1993; Souza \& Silva, 2012; Santana \& Borba, 2015).

Lastly, the behaviorist theories have relevant collaborators such as the work of Robert W. White (White, 1959) who developed the "theory of effectance motivation", as well as the scholars Edward L. Deci and Richard M. Ryan (1985) who developed the "theory of self-determination" (Deci \& Ryan, 1985; Pansera et al., 2016).

It was verified an increased effort to understand motivated the individual with autonomous behavior, according to the context and the commitment to an activity in the degree that it is agreeable, according to basic needs and to a self-determination continuum.

These theories demonstrate different aspects of human development, considering the personal ability to seek paths of assimilating experience and abilities in an active manner, which is agreeable and intrinsically motivated to overcome the challenges in one's own development and learning process (Ostermann \& Cavalcanti, 2011).

Mapping these theories propels the reflection regarding the implications to the education process, in this sense the teacher is not a mere information trans- 
mitter, but a facilitator in the edification of knowledge, in face of a student who is stimulated to learn, interacting actively with the context and environment in which she lives.

The student who chooses a nursing graduation for personal reason establishes an objective to be reached, knows the importance and the value of the training, also needs support from the environment and context, contributing to a higher level of wellness and satisfaction, in a positive motivation atmosphere. Regarding higher education, research suggests students in a course that was not their first option remained because they were satisfied with the quality of the institution's organization, with the involvement of professors and with the practical components of the course (Albuquerque, 2008). The impairment of the student's reflection considering the process of choosing nursing as a professional option can collaborate in generating a posture of disinterest and demotivation, since the student would be studying a subject that does not contribute to the promotion of their expectations that could be enhanced with a greater integration of the individual, due to the possibility of choosing his path for development.

It was identified a greater incident of dropout from the nursing course in the first years of the course in students who opted for the nocturnal period (Adachi, 2017). Research analyzes the rate of dropout with higher incidence in the first years considering aspects such as lack of maturity and dissatisfaction with the education system. Despite all the difficulties faced, a great part of the students did not dropout from the course, which could be related to a more adult population, leading to a smaller rate of dropout throughout the course (Barlem et al., 2012).

As such, the hypothesis for this paper is that the student is unmotivated as a response to expectations being frustrated in the academic context, due to educators' attitude and teaching strategies that follow a traditional model, which considers the transmission of knowledge and content in a passive format.

The frustrated expectations considering the academic environment in face of the context and academic perspectives demonstrate an influence of the environment in the students' academic life and motivation. One expects that the educators would have an attitude as a facilitator, understanding how academic motivation is edified and which factors contribute to the students' demotivation (Alderman, 2003).

It is known that the education method can facilitate (or impair) a student regarding self-determination which contributes to personal development and satisfaction throughout the course. Students' unique characteristics can lead to an adaptation to traditional education format, lacking development of autonomy, competency, assuming a passive role, not participating actively in the proposed activities and displaying a passive and mechanical attitude towards the subject, which, at times, does not contribute to an actively critical and reflexive behavior in the professional training (Lazzari et al., 2011).

The general objective of this study is to evaluate undergraduate nursing students' academic motivation through the self-determination perspective. As specific objectives, this research proposes to describe a group of nursing students in 
terms of the sociodemographic data and to identify variables associated to undergraduate nursing students' motivation profile.

In view of this, the present research focuses on motivation of undergraduate nursing students in Praia Grande/SP. This town located in the south coast of Sao Paulo has a population of about 300.000 and a local public policy that pays a special attention to higher education of quality and to the improvement of professional public servants' technical level. The town's inhabitants and those from Baixada Santista/SP region are engaged in the workforce to attend to society's health as well as to the market's demand in the area, fomenting training for SUS (Brazilian Unified Public Health System) and improving the service of Family Health Strategy.

Most students correspond to workers in the public sector of the town in various areas and others that work in health, practicing as nurse aide and technical assistant. One observes difficulty in the access to higher education according to the social demographic profile analyzed empirically. Therefore, the search for higher education in nursing can be related to financial aid opportunities for academic and professional development.

This research was based upon the self-determination theory, which will be introduced posteriorly with the aim to reflect upon the academic track of nursing students, related to social-contextual factors that interfere in people's lives, in the pursuit of fulfilling basic psychological needs for competency, relationships, and autonomy, and consequently a higher social integration, wellness, commitment, and motivation (Ryan \& Deci, 2017).

As one of the current leading theories, the self-determination theory studies how people perform their tasks by analyzing interests, causes and effects of self-determined behaviors, considering that the basic psychological needs are fulfilled satisfactorily. In the academic context, while the professors mediate the classroom environment, from the point of view of self-determination, it is important to study attitudes and procedures which provide a sense of satisfaction, in especial considering the social context in which the individual is inserted. The three basic psychological needs are: autonomy, competency, and interpersonal relationship, building relatedness and affection, which increases satisfaction and motivation (Zanetti, Feltran, Polito, Dias, Neves, \& Brandão, 2017; Bernardino, Coriolano-Marinus, Santos, Linhares, Cavalcanti, \& Lima, 2018).

Based on the above considerations, it becomes necessary to investigate the motivation of nursing students, to contribute to the betterment of the training process and its importance to the academic society awareness of the nature of building scientific knowledge and significant learning.

\section{Objectives}

This paper aims to examine nursing students' academic motivation under the self-determination theory. As such, the question which guided the research is: What is the motivation for nursing students, considering knowledge, compe- 
tency, self-esteem, autonomy, interest, and satisfaction?

Our specific objectives are to examine undergraduate nursing students in terms of sociodemographic data and to identify variables associated to their motivational profile.

\section{Methodology}

\subsection{Ethical Aspects}

This research was approved by the Ethics and Research Committee Brazil Platform as recommendation by Resolution 466/12 of National Health Council (Ministério da Saúde, 2012). It was composed as part of a dissertation for the Professional Master's Degree in Health Higher Education of the Sao Caetano University Graduate Program. The research has its own funding and the authors declared not to have any conflict of interests.

\subsection{Outline, Place of Study, Period}

The present study is descriptive research with a quantitative approach. The data were first collected in the period from February to March, and, in a second moment, from July to August 2020, in a college in Praia Grande, Sao Paulo.

\subsection{Population and Sample: Criteria for Inclusion and Exclusion}

Over the time of collecting data, school year of 2020, the college had 407 officially registered students in the undergraduate nursing program, who were 18 years old or older, of both sexes, who were willing to participate voluntarily in the research.

The sample which supports the research was collected as a convenience sampling, dismissing sample calculation in which data are collected to test a hypothesis, based on numeric measurement and in the statistical analysis to establish patterns and demonstrate theories (Collado et al., 2013).

The criteria for inclusion were the following: participants registered in undergraduate nursing course and who voluntarily accepted to participate. The criteria for exclusion were constituted by any problems which prevented the student from participating, such as not having access to the Internet and difficulty in accessing the link for the online research.

\subsection{Study Protocol}

The data were collected using an online questionnaire developed from Google Forms. Only after signing an electronic informed consent form was the student able to answer the online questionnaire, with a link for exclusive access.

The first data collection was realized in the months of February to March of 2020 with 232 years. Due to the new coronavirus COVID-19 pandemic, it was decided to implement an extension of the study in the new context. A new data collection was implemented in July and August with 228 years. The recommendation of social distancing was followed, according to the health authorities and 
current legislation during the coronavirus pandemic (COVID-19), carrying out data collection in a remote manner via online.

It is important to emphasize that the same apparatus was used, with the same research objective. For the data collection two apparatus were applied in two moments: the first moment consisted of collecting information to create a student's profile, with information which was considered relevant to the research. In the second moment the research applied the Academic Motivation Scale to learn about the types of nursing students' motivation in the academic context. The scale is composed of 28 questions divided in seven subscales with four items for each analyzed motivation. Scores were taken using the Likert scale (Lucian \& Dornelas, 2015).

Moment I-Questionnaire for Students' General Data: demographic and context variables, elaborated especially for this research. Moment II-Application of the Academic Motivation Scale (AMS): considered main part of the data collection, elaborated by Vallerand (Vallerand, Blais, Brière, \& Pelletier, 1989), translated and validated in Portuguese by D. T. Sobral (Sobral, 2003).

\subsection{Statistical Data Analysis}

After the data were collected for analysis, a data bank was developed using Excel spreadsheet for Windows, and which was analyzed by a statistician. This analysis was based on descriptive and inferential statistics. The research used the Wilcoxon-Mann-Whitney U test, Pearson's Chi-Squared and Fisher's exact test for data analysis. The results are presented in format of tables and analyzed according to the current and classic literature (Gil, 2017).

\section{Results}

\subsection{Sociodemographic Profile}

In total 232 students participated in the study's first data collection in February and March, and a total of 228 students participated in the second data collection in July and August of 2020.

In Table 1 data are presented in terms of sociodemographic characteristics of students who participated in the research. The profile ranges from age 18 - 57 years old, predominately of the female sex, living in Praia Grande, on financial aid, the majority of which by the city's local government. There were students that participated in the research who had failed classes and concluded the coursework, some who dropped out and others took a leave of absence. Over half the students had previous training as nursing's aide or technician.

In Table 2, it was verified that a great part of the students works in the nursing area, however some study nursing but work in a practice outside the nursing area. A great majority expressed to participate in the nursing undergraduate course with commitment. Among the participants, students graduated over the course of the data collection, after finishing any incomplete class, others took a leave of absence and another group dropped out of the course. 
Table 1. Distribution of students in terms of the sociodemographic data collection in the first moment $\left(\mathrm{n}_{1}\right)$ and in the second data collectiom $\left(\mathrm{n}_{2}\right)$. Praia Grande, Sao Paulo, Brasil, 2020 .

\begin{tabular}{|c|c|c|c|c|}
\hline \multicolumn{5}{|l|}{ Variable } \\
\hline & $\mathrm{n}_{1}$ & $\%$ & $\mathbf{n}_{2}$ & $\%$ \\
\hline \multicolumn{5}{|l|}{ Age } \\
\hline 18 - 24 years old & 87 & 37.6 & 70 & 30.7 \\
\hline 25 - 34 years old & 57 & 24.5 & 53 & 23.3 \\
\hline 35 - 44 years old & 57 & 24.5 & 79 & 34.6 \\
\hline 45 - 57 years old & 31 & 13.4 & 26 & 11.4 \\
\hline \multicolumn{5}{|l|}{ Sex } \\
\hline Female & 194 & 83.7 & 209 & 91.7 \\
\hline Male & 37 & 15.9 & 19 & 8.3 \\
\hline Others & 1 & 0.4 & 0 & 0 \\
\hline \multicolumn{5}{|l|}{ Location during the course } \\
\hline From Praia Grande and lives in Praia Grande & 187 & 80.6 & 180 & 78.9 \\
\hline From another town and lives in Praia Grande & 18 & 7.8 & 16 & 7.0 \\
\hline From another town & 27 & 11.6 & 32 & 14.1 \\
\hline \multicolumn{5}{|l|}{ Financial Aid } \\
\hline City's Local Government & 181 & 78.1 & 194 & 85.1 \\
\hline Federal Funding (PróUni/FIES) & 27 & 11.6 & 26 & 11.4 \\
\hline Paying Student & 24 & 10.3 & 8 & 3.5 \\
\hline \multicolumn{5}{|l|}{ Course Year } \\
\hline $1^{\text {st }}$ year & 44 & 18.9 & 53 & 23.2 \\
\hline $2^{\text {nd }}$ year & 31 & 13.4 & 22 & 9.6 \\
\hline $3^{\text {rd }}$ year & 32 & 13.8 & 51 & 22.5 \\
\hline $4^{\text {th }}$ year & 43 & 18.5 & 44 & 19.3 \\
\hline $5^{\text {th }}$ year & 48 & 20.7 & 34 & 14.9 \\
\hline Graduating & 15 & 6.5 & 11 & 4.8 \\
\hline Dropout & 6 & 2.6 & 6 & 2.6 \\
\hline Leave of Absence & 13 & 5.6 & 7 & 3.1 \\
\hline \multicolumn{5}{|l|}{ Previous trainning } \\
\hline Previous trainning as nursing technician/aide & 151 & 65.1 & 159 & 69,7 \\
\hline Without previous trainning as nursing technician/aide & 81 & 34.9 & 69 & 30.3 \\
\hline TOTAL* & 232 & 100 & 228 & 100 \\
\hline
\end{tabular}

${ }^{*}$ Total of participating students who answered the specific item.

After applying Pearson's Chi-Squared Test it was observed significant statistic of students already working in the nursing technical area $(p<0.001)$.

In Table 3 , it is noticeable that a great majority of students chose the nursing 
Table 2. Distribution of students in term of employment in nursing or in activity outside of the nursing area and participation in the course, in the first moment of collection $\left(\mathrm{n}_{1}\right)$ and in the second moment $\left(\mathrm{n}_{2}\right)$. Praia Grande, Sao Paulo, Brasil, 2020.

\begin{tabular}{ccccc}
\hline & Variable & & & \\
\hline & $\mathrm{n}_{1}$ & $\%$ & $\mathbf{n}_{2}$ & $\%$ \\
\hline Employment in nursing & & & & \\
Working in the techinical area of nursing & 105 & 45.3 & 111 & 48.7 \\
Working in another area & 57 & 24.5 & 62 & 27.2 \\
Only studying undergraduate nursing & 35 & 15.1 & 31 & 14 \\
Others* & 35 & 15.1 & 23 & 10.1 \\
Activity outside of nursing area & & & & \\
No & 121 & 52.1 & 139 & 60.9 \\
Maybe & 70 & 30.2 & 58 & 25.5 \\
Yes & 41 & 17.7 & 31 & 13.6 \\
Participation in the course & & & & \\
With commitmment & 224 & 96.6 & 223 & 97.8 \\
Toty to graduate and work in the area & 8 & 3.4 & 5 & 2.2 \\
TOT & 232 & 100 & 228 & 100 \\
\hline
\end{tabular}

*Total of participating students who answered the specific item; ${ }^{* *}$ Graduating (15), leave of absence (14) and dropped out (6).

Table 3. Distribution of students in term of the choice for nursing undergraduate course in the first moment $\left(n_{1}\right)$ and in the second moment $\left(n_{2}\right)$.

\begin{tabular}{ccccc}
\hline Variable & & & & \\
\hline $\begin{array}{c}\text { Motivation for choosing the undergraduate nursing course } \\
\text { Desire to study and work in the area }\end{array}$ & $\mathrm{n}_{1}$ & $\%$ & $\mathbf{n}_{2}$ & $\%$ \\
Personal desire & 107 & 46.1 & 110 & 48.2 \\
Encouragement from family and friends & 88 & 37.9 & 74 & 32.5 \\
Not getting into another course & 20 & 8.6 & 30 & 13.2 \\
Others & & & \\
(** & 6 & 2.7 & 4 & 1.7 \\
Decision to enroll in undergraduate nursing course & 11 & 4.7 & 10 & 4.4 \\
To improve professional performance & & & & \\
To receive graduation diploma & 179 & 77.2 & 178 & 78.1 \\
To take care of a personal issue & 16 & 6.9 & 8 & 3.5 \\
To meet employer's recommendation & 9 & 3.9 & 7 & 3.1 \\
Others & $1 * *$ & 0.4 & 1 & 0.4 \\
TOTAL & 27 & 11.6 & 34 & 14.9 \\
\hline
\end{tabular}

*Total of participating students who answered the specific item; ${ }^{*}$ Others: to help people, because of not being accepted into medicine, love for the health area and admiration; ${ }^{* *}$ Others: Military Tenders, desire to be in the nursing practice, to take care of others and to acquire knowledge. 
undergraduate course to fulfill a desire to study and work in the nursing area and chose nursing to improve their professional performance.

Table 4 describes the mean and standard deviation in the Academic Motivation Scale. It was made evident that there was no significant difference statistically between the first and the second moments of data collection for whichever intrinsic and extrinsic motivation analyzed. However, the test for comparing the means was significant with moderate evident $(p=0.011)$ for demotivation.

\subsection{Evaluation of Academic Motivation}

The results point to a self-determined motivation profile of students who undertake the nursing course, with higher levels of self-dependency, characterizing students committed to fulfilling their needs for personal and professional development. However, considering the data analysis in outliers (boxplot), it is important to highlight small groups of students who demonstrated lack of motivation (A) (Figure 1).

In the first moment of data collection, students who chose to be in the undergraduate nursing course did it of their own accord, to improve themselves professionally, motivated by the stimulus from family and friends or to meet the demands of the employment.

In the second moment of data collection, students reported the choice for the higher education in nursing was motivated by a desire to work in the area, of own accord, to improve their professional practice and moreover receive a certificate.
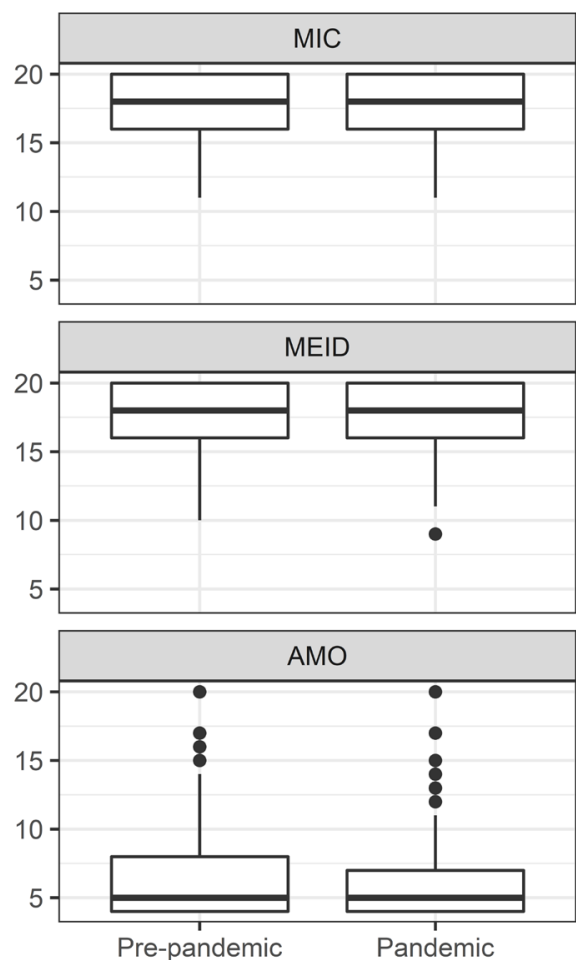
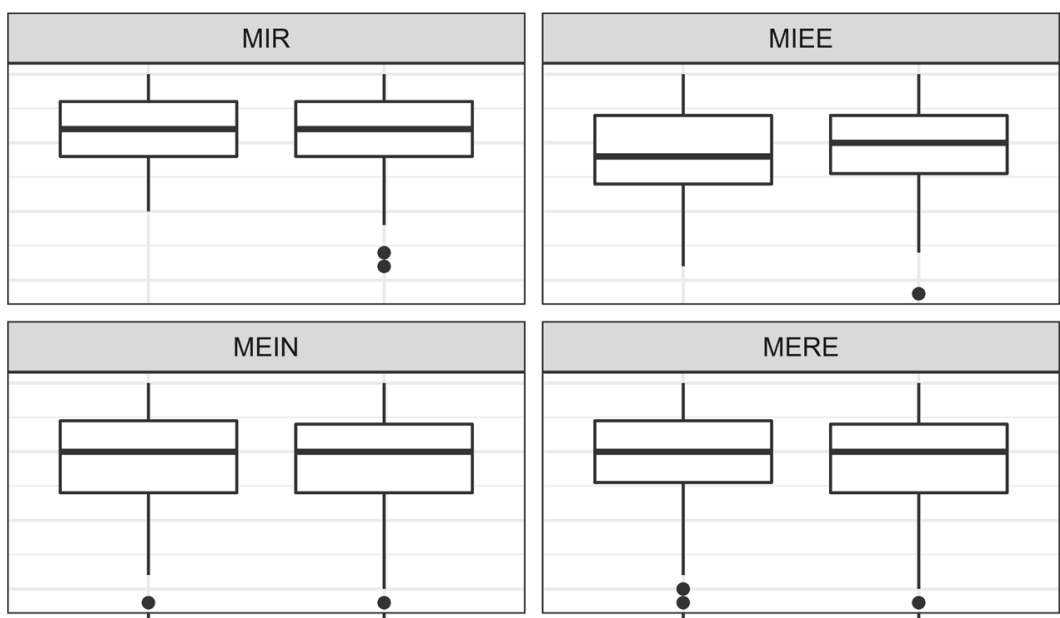

Pre-pandemic Pandemic

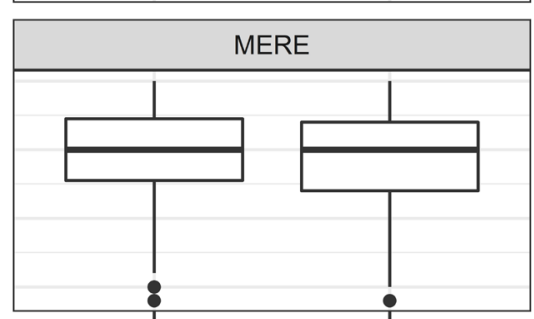

Pre-pandemic Pandemic

Figure 1. Distribution of variables pre-pandemic and post-pandemic. Praia Grande, Sao Paulo, Brazil, 2020. 
Table 4. The mean and standard deviation of academic motivation scale in the first moment $\left(\mathrm{n}_{1}\right)$ and in the second moment $\left(\mathrm{n}_{2}\right)$.

\begin{tabular}{|c|c|c|c|}
\hline \multirow{2}{*}{ Academic Motivation } & \multirow{2}{*}{\multicolumn{3}{|c|}{$\begin{array}{l}1^{\text {st }} \text { collection } 2^{\text {nd }} \text { collection Standardized } \\
\text { Mean (PD) Mean (PD) value* }\end{array}$}} \\
\hline & & & \\
\hline \multicolumn{4}{|l|}{ Intrinsic Motivation } \\
\hline Intrinsic Motivation towards Knowledge (IMk) & $6.06(0.04)$ & $6.09(0.14)$ & 0.835 \\
\hline Intrinsic Motivation towards Accomplishment (Ima) & $5.22(0.47)$ & $5.62(0.49)$ & 0.532 \\
\hline Intrinsic Motivation to Stimulating Experience (IMse) & $4.99(0.16)$ & $5.07(0.11)$ & 0.470 \\
\hline \multicolumn{4}{|l|}{ Extrinsic Motivation } \\
\hline Extrinsic Motivation-Identification (EMidr) & $6.09(0.30)$ & $6.11(0.37)$ & 0.786 \\
\hline Extrinsic Motivation-Introjection (EMintr) & $5.05(0.48)$ & $5.08(0.38)$ & 0.684 \\
\hline Extrinsic Motivation-External Regulation (EMer) & $5.19(0.39)$ & $4.97(0.58)$ & 0.353 \\
\hline \multicolumn{4}{|l|}{ Demotivation } \\
\hline Amotivation (A) & $2.30(0.53)$ & $2.13(0.35)$ & 0.011 \\
\hline
\end{tabular}

*Wilcoxon-Mann-Whitney U test.

\section{Discussion}

\subsection{Sociodemographic Profile}

In this research, it was verified a homogenous distribution by age. A similar result was found in Brazilian nursing profile (COFEN, 2013). In the second moment, the students were around two years older on average $(p=0.04)$, Among the participants in this study, there was a small number of students who left $(12.6 \%)$ due to graduating from the course, dropping out or taking a leave of absence.

Despite all the difficulties faced, a great part of the students did not abdicate from concluding the course, which could be related to the fact that they are part of a more adult population, producing a lower level of dropping out of the course (Barlem, Bordignon, Barlem, Lunardi et al., 2012). It was identified a predominance of women in the study (COFEN, 2018). In term of location, 79.7\% lived in Praia Grande during the course.

The research identified that the great majority of students had financial aid offered by Praia Grande's local government (81.6\%) and by federal government programs which facilitate access to higher education" PROUNI (University to all Program) and FIES (Fund for Financing Higher Education), PROUNI/FIES $(11.5 \%)$ in a total of $93.1 \%$ of students who receive financial aid.

Investing in financial aid for higher education, according to the priorities of service demands encountered in the SUS (Unified Public Health System) and Strategy for Family Health, created an efficient and inclusive partnership between the college, local and national government, which work together in search of technical development, sharing knowledge and social impact in a commitment to people's health through innovative practices in health higher education (Morosini \& Mentges, 2020). 
With respect to student distribution by course level, there was a participation of all course years homogeneously. It is worth noting that the sample was chosen by convenience of access to students of all course years during data collection for this research.

A great part of the students $(67.4 \%)$ in this study had previous training as nursing aide or technician. Aides and technicians seek to elevate their professional practice, which could be traced back to demands that come from their employment, such as problem solving, technical scientific knowledge, creativity, initiative, communication, and ability to work with other people (Kurcgant, 2011).

According to statistical analysis, in the first moment of data collection there were more men $(p=0.027)$, and in the second moment of data collection there was a decrease in terms of students without financial aid $(p=0.04)$ and of the students coursing the fourth and fifth year of nursing, with a significant statistic $(p<0.001)$, which could be related to the availability of the students to participate in the research.

The research identified that a great part of the participants studied and worked in the nursing area (47\%), did not have any intention of leaving the practice $(56.5 \%)$ and reported to participate in the nursing course with commitment (97.2\%). Considering the experiences both individual and social, the personal and professional identity moves towards a consolidation and aggregates a higher-level demand for studying, according to motivation and factors related to the choices and manner of carrying out their professional training (Melo, Assunção, Resck, Lima, \& Sanches, 2020).

It was verified a significant statistic of students already working in the nursing area $(p<0.001)$. The choice for nursing course could be related to an innate desire to care for people which results in the need for a professional training, related to professional identity, meaning and peculiarities (Teodosio \& Padilha, 2016).

\subsection{Evaluation of Academic Motivation}

Considering the intrinsic and extrinsic motivation evaluated, there was no significant statistical difference between the first and the second moment of data collection. During the pandemic, students' motivation did not change considerably, which could be related to students' aspiration to continue in their studies, and not to miss the opportunity to have a higher education funded, as well as to carry out the academic training for the area in which they already work.

The research verified that students showed higher scores in motivation scale: Extrinsic Motivation-Identification (EMi) and Intrinsic Motivation towards Knowledge (IMk). There was a reduction in the mean for Extrinsic Motivation-External Regulation (EMer), comparing the results from the first data collection to the second. However, there was no significant difference statistically between the two moments $(p=0.353)$, which could be explained by the fact that the students are in a remote learning context, with a less strictly implemented evaluation 
process and lack of absence monitoring by the faculty, once the difficulties and adversities were considered, with lesser pressure or expectation for either reward or punishment (Davoglio, Santos, \& Lettnin, 2016).

The analysis found that for amotivation, the test to compare the means was significant with moderate evidence $(p=0.011)$. Studies show that the approach to emergency plan for distance learning in nursing influenced the context, regarding doubts, fears and individual difficulties imposed by the social situation, such as any problem which hindered the student from participating in the academic activities during the pandemic (Costa, Lino, Souza, Lorenzini, Fernandes, $\&$ Brehmer, 2020).

Based on outlier's data analysis, the research identified smaller groups of students who showed lack of motivation (A). These data could be related to students' concern in meeting the demands of the work market, stimulus from important people in their lives and job maintenance, without the commitment to fulfilling their own needs. Amotivation could possibly be related to the academic path, traditional format of teaching and sharing knowledge as a way of meeting the needs of the educational marked (Morosini \& Mentges, 2020; Fritsch Jacobus \& Vitelli, 2020).

\subsection{Research Limitations}

The limitations of this research occurred by the impediment of realizing interviews on the totality of the students, either by part of the students' refusal to participate in the research or by being situated only in one college.

\subsection{Contributions to Education, Health or Public Policy}

Learning about the nursing students' academic motivation profile contributes to steering the nursing courses in view of the enhancement of the teaching-learning process and to the students' development, consequently having a better trained professional for the workforce, with higher level of wellness and higher satisfaction, in a continuous self-determination process, effective and significant learning to the excellence of professional training in nursing practice as well as an efficient and humanized health system, which could offer paths to a higher quality of motivation, focusing on fomenting motivated and commitment students to the excellence in caring.

The expectation is that this study can be a contribution to the reflection by other higher education institutions, supporting the academic practice by adopting education strategies in nursing training, elaborating core curriculum, planning and promoting alignment between nursing educational institutions and other health higher education professions, in order to foment innovation in health education, guided by a holistic and humanized perspective, which point to quality and responsibility in caring.

It is suggested meetings for training of educators directed by models and methodologies of active learning: Problem Based Learning (PBL), Team-Based Lear- 
ning (TBL), Peer Instruction (PI) and Learning Based on Projects (Lacerda \& Santos, 2018; Aguiar \& Andrea, 2018).

This study proposes the relevance of these findings for educators in undergraduate courses, stimulating a participation in a critical and reflexive manner, bringing their experiences and collaboration to choosing evaluative methods compatible with educational purposes of the academic institution.

The researchers recommend the Miller pyramid to be considered in the choice of evaluative methods, in a continuous process of development in which the student must acquire understanding (knowledge), acquire practices (reporting and describing), realize these in simulated scenarios (demonstrate how the practice is undertaken) (Van Der Valeuten \& Schuwirth, 2005). Educators' active participation incorporates the proposed content in the undergraduate courses can be evaluated by the following methods: exams with objective and essay questions, work in small groups, Osce, Mini-Dex and portfolio (Silva et al., 2017).

\section{Conclusion}

The data in this research demonstrate that students have self-determining motivations in view of their academic planning and drive. This fact is important for a higher-level learning, self-determining motivation, social integrational, satisfaction, wellness, involvement, and dedication by the students.

The evaluation of small groups of students which showed lack of motivation (A), points to a path of examination to elaborate educational strategies which could lead to a better training and performance by the teaching staff, with practices that reinforce the research, a learning-teaching process of quality and continuity of students who reach graduation from the course.

Thus, effective practices for nursing education should be guided by an intensification of teaching strategies focused on examination and enhancement that could show paths for the reinforcement and innovation of higher education in nursing.

\section{Conflicts of Interest}

The authors declare no conflicts of interest regarding the publication of this paper.

\section{References}

Adachi, A. A. C. T. (2017). Evasão de estudantes de cursos de graduação da USP: Ingressantes nos anos de 2002, 2003 e 2004. Tese de Doutorado. Universidade de São Paulo.

Aguiar, M. J., \& Andrea, P. S. (2018). Metodologias Ativas: Aprendizagem Baseada Em Problemas, Problematização e Método Do Caso. Cadernos de Educação, Tecnologia e Sociedade (Brazilian Journal of Education, Technology and Society), 11, 404-415. https://doi.org/10.14571/brajets.v11.n3.404-415

Albuquerque, T. (2008). Do abandono à permanência num curso de ensino superior. Sísifo: Revista de Ciências da Educação, 7, 19-28.

Alderman, M. K. (2003). Motivation for Achievement: Possibilities for Teaching and Lear- 
ning. Routledge.

Bandura, A. (1986). The Explanatory and Predictive Scope of Self-Efficacy Theory. Journal of Social and Clinical Psychology, 4, 359-373. https://doi.org/10.1521/jscp.1986.4.3.359

Bandura, A. (1993). Perceived Self-Efficacy in Cognitive Development and Functioning. Educational Psychologist, 28, 117-148. https://doi.org/10.1207/s15326985ep2802 3

Bandura, A., \& Walters, R. H. (1963). Social Learning and Personality Development. Holt Rinehart and Winston.

Barlem, J. G. T., Lunardi, V. L., Bordignon, S. S., Barlem, E. L. D, Lunardi, Filho W. D. Silveira, R. S., \& Zacarias, C. C. (2012). Opção e evasão de um curso de graduação em enfermagem: Percepção de estudantes evadidos. Revista Gaúcha de Enfermagem, 33, 132-138. https://doi.org/10.1590/S1983-14472012000200019

Bernardino, A. O., Coriolano-Marinus, M. W. L., Santos, A. H. S., Linhares, F. M. P., Cavalcanti, A. M. T. S., \& Lima, L. S. (2018). Motivação dos estudantes de enfermagem e sua influência no processo de ensino-aprendizagem. Texto Contexto Enfermagem, 27, Article ID: e1900016. https://doi.org/10.1590/0104-070720180001900016

Collado, C. F., Lúcio, M. P. B., \& Sampieri, R. H. (2013). Metodologia de pesquisa. Penso.

Conselho Federal de Enfermagem (COFEN) (2013). Enfermagem em números. http://www.cofen.gov.br/perfilenfermagem/index.html

Conselho Federal de Enfermagem (COFEN) (2018). Enfermagem em números. http://www.cofen.gov.br/enfermagem-em-numeros

Costa, R., Lino, M. M., Souza, A. I. J., Lorenzini, E., Fernandes, G. C. M., Brehmer, L. C. F., Vargas, M. A. O., Locks, M. O. H., \& Gonçalves, N. (2020). Ensino de Enfermagem em tempos de COVID-19: Como se reinventar nesse contexto? Texto Contexto Enfermagem, 29, Article ID: e20200202.

https://doi.org/10.1590/1980-265X-TCE-2020-0002-0002

Davoglio, T. R., Santos, B. S., \& Lettnin, C. C. (2016). Validação da Escala de Motivação Acadêmica em universitários brasileiros. Ensaio: Aval Políticas Públicas Educacionais, 24, 522-545. https://doi.org/10.1590/S0104-40362016000300002

Deci, E. L., \& Ryan, R. M. (1985). Intrinsic Motivation and Self-Determination in Human Behavior. Perspectives in Social Psychology. Springer.

https://doi.org/10.1007/978-1-4899-2271-7

Dewey, J. (1986). Experience and Education. The Educational Forum, 50, 241-252. https://doi.org/10.1080/00131728609335764

Fritsch, R., Jacobus, A. E., \& Vitelli, R. F. (2020). Diversificação, mercantilização e desempenho da educação superior brasileira. Avaliação: Revista Avaliação Educação Superior, 25, 89-112. https://doi.org/10.1590/S1414-40772020000100006

Gil, A. C. (2017). Como elaborar projetos de pesquisa (6th ed., p. 192). Atlas.

Hull, C. L. (1943). Principles of Behavior: An Introduction to Behavior Theory. AppletonCentury.

Kurcgant, P. (2011). Nurses' Professional Training. Editorial. Revista da Escola de Enfermagem da USP, 45, 307-308. https://doi.org/10.1590/S0080-62342011000200001 https://www.scielo.br/pdf/reeusp/v45n2/en v45n2 editorial.pdf

Lacerda, F. C. B., \& Santos, L. M. (2018). Integralidade na formação do ensino superior: Metodologias ativas de aprendizagem. Avaliação: Revista da Avaliação da Educação Superior, 23, 611-627. https://doi.org/10.1590/S1414-40772018000300003

Lazzari, D. D., Pedro, E. N. R., Márcia, O. S., \& Jung, W. (2011). Estratégias de ensino do 
cuidado em enfermagem: Um olhar sobre as tendências pedagógicas. Revista Gaúcha de Enfermagem, 32, 688-694. https://doi.org/10.1590/S1983-14472011000400008

Lobos, J. (1975). Teorias sobre a motivação no trabalho. Revista de Administração de empresas, 15, 17-25. https://doi.org/10.1590/S0034-75901975000200002

Lucian, R., \& Dornelas, J. S. (2015). Mensuração de atitude: Proposição de um protocolo de elaboração de escalas. Revista de Administração Contemporânea, 19, 157-77. https://doi.org/10.1590/1982-7849rac20151559

McDougall, W. (1923). Purposive or Mechanical Psychology? Psychological Review, 30, 273-288. https://content.apa.org/doi/10.1037/h0074955

Melo, M. L., Assunção, M. R. S., Resck, Z. M. R., Lima, R. S., \& Sanches, R. S. (2020). Escolha dos técnicos de enfermagem pelo curso de graduação na área: Motivos e perspectivas. Brazilian Journal Development, 6, 77704-77719.

Ministério da Saúde (BR) (2012). Dispõe sobre pesquisa envolvendo seres humanos. Resolução No. 466/12. http://bvsms.saude.gov.br/bvs/saudelegis/cns/2013/res0466 $12 \quad 12$ 2012.html

Morosini, M. C., \& Mentges, M. J. (2020). Organismos internacionais e educação superior: Proposições da agenda E2030. ETD-Educação Temática Digital, 22, 632-650. https://doi.org/10.20396/etd.v22i3.8659308

Muacho, M. (2013, May). Contribuição Das Diferentes Teorias Para A Compreensão Do Processo Motivacional. Research Gate. https://www.researchgate.net/publication/273741440 CONTRIBUICAO DAS DIFER ENTES TEORIAS PARA A COMPREENSAO DO PROCESSO MOTIVACIONAL

Murray, E. J. (1964). Motivation and Emotion. Prentice-Hall.

Ostermann, F., \& Cavalcanti, C. J. de H. (2011). Teorias de aprendizagem. Evangraf.

Pansera, S. M., Valentini, N. C., Souza, M. S., \& Berleze, A. (2016). Motivação intrínseca e extrínseca: Diferenças no sexo e na idade. Psicologia Escolar e Educacional, 20, 313-320. https://doi.org/10.1590/2175-353920150202972

Rotter, J. B. (1954). Social Learning and Clinical Psychology. Prentice-Hall.

Rotter, J. B. (1966). Generalized Expectancies for Internal versus External Control of Reinforcement. Psychological Monographs: General and Applied, 80, 1-28. https://doi.apa.org/doi/10.1037/h0092976

Ryan, R. M., \& Deci, E. L. (2017). Self-Determination Theory: Basic Psychological Needs in Motivation, Development, and Wellness (756 p). Guilford Publications. https://doi.org/10.1521/978.14625/28806

Sampaio, A. A. S. (2005). Skinner: Sobre ciência e comportamento humano. Psicologia: ciência e profissão, 25, 370-383. https://doi.org/10.1590/S1414-98932005000300004

Santana, L. H., \& Borba, A. (2015). Edward Chace Tolman e o uso da aprendizagem latente e do reforçamento como princípios explicativos. Acta Comportamentalia: Revista Latina de Análisis de Comportamiento, 23, 199-211.

Schwartz, S. (2019). Motivação para ensinar e aprender: Teoria e prática. Editora Vozes Limitada.

Silva, A. T. C., de Medeiros Junior, M. E., de Nogueira Fontão, P., Filho, H. C. S., Félix Vital Junior, P., Bourget, M. M. M. et al. (2017). Medicina de Família do primeiro ao sexto ano da graduação médica: considerações sobre uma proposta educacional de integração curricular escola-serviço. Revista Brasileira de Educação Médica, 41, 336-345. https://doi.org/10.1590/1981-52712015v41n2RB20160016

Skinner, B. F. (1958). Teaching Machines. Science, 128, 969-977. 
https://doi.org/10.1126/science.128.3330.969

Sobral, D. T. (2003). Motivação do aprendiz de medicina: Uso da escala de motivação acadêmica. Psicologia: Teoria e Pesquisa, 19, 25-31. https://doi.org/10.1590/S0102-37722003000100005

Souza, C., \& Silva, R. (2012). Teoria das expectativas de Vroom. Paracatu, Brasil. Disponível a, 12, 1-16.

Teodosio, S. S. C., \& Padilha, M. I. (2016). To Be a Nurse: A Professional Choice and the Construction of Identity Processes in the 1970s. Revista Brasileira de Enfermagem, 69, 428-434. https://doi.org/10.1590/0034-7167.2016690303i

Thorndike, E. L. (1913). Educational Psychology: The Original Nature of Man (Vol. 1). Teachers College. https://psycnet.apa.org/doi/10.1037/13763-000

Tolman, E. C. (1932). Purposive Behavior in Animals and Men. University of California Press.

Vallerand, R. J., Blais, M. R., Brière, N. M., \& Pelletier, L. G. (1989). Construction et validation de l'échelle de motivation en éducation (EME) [Construction and Validation of the Motivation toward Education Scale]. Canadian Journal of Behavioural Science/ Revue canadienne des sciences du comportement, 21, 323-349. https://doi.apa.org/doi/10.1037/h0079855

Van Der Valeuten, C., \& Schuwirth, L. (2005). Assessing Professional Competence: From Methods to Programmes. Medical Education, 39, 309-317.

https://doi.org/10.1111/j.1365-2929.2005.02094.x

Vroom, V.H. (1964). Work and Motivation. Wiley.

Watson, J. B. (1912). Literature for 1911 on the Behavior of Vertebrates. Journal of Animal Behavior, 2, 421-440. https://doi.apa.org/doi/10.1037/h0074340

Watson, J. B. (1913). Psychology as the Behaviorist Views It. Psychological Review, 20, 158-177. https://doi.apa.org/doi/10.1037/h0074428

White, R. W. (1959). Motivation Reconsidered: The Concept of Competence. Psychological Review, 66, 297-333. https://content.apa.org/doi/10.1037/h0040934

Woodworth, R. S. (1918). Dynamic Psychology. Columbia University Press. https://doi.org/10.7312/wood90908

Zanetti, M. C., Feltran, G. N., Polito, L. F. T., Dias, H. M., Neves, A. N., \& Brandão, M. R. F. (2017). An Intervention Program on Motivation and Psychological Needs in Physical Education. Universidad de Almería. Universitat. Autònoma de Barcelona. Revista de Psicología del Deporte, Journal of Sport Psychology, 26, 34-38.

https://ddd.uab.cat/pub/revpsidep/revpsidep a2017v26sup4/revpsidep a2017v26n6p34 .pdf 